\title{
Coexpression of Methicillin-resistant S. aureus and ESBL Producing E. coli in Mastitic Milk of Buffaloes
}

\author{
A. Lade, J. Jogi, A. Nayak, R.V. Singh, A. Rai, P. Shakya, K. Himani, S. Bordoloi
}

10.18805/IJAR.B-4835

\begin{abstract}
Background: Mastitis is mostly caused by mixed infections, of which $S$. aureus and $E$. coli are amongst the most important bacteria. Detection of resistant strains of these bacteria is a major public health concern due to the possibility of infection via contaminated milk and milk products intended for human consumption. This study describes simultaneous occurance of methicillin-resistant S. aureus and extended spectrum $\beta$-lactamase producing E. coli in mastitic milk samples of buffaloes in Jabalpur, India.

Methods: A total of 408 buffaloes milk samples were screened for mastitis by California mastitis test (CMT) test. A total of 102 mastitic milk samples were collected for isolation of Staphylococcus aureus (S. aureus) and Eschirichia coli (E. coli). Polymerase chain reaction was performed for molecular characterization of methicillin resistant $S$. aureus for mecA gene and ESBL producing E. coli for bla TEM gene, respectively.

Result: On the basis of cultural and biochemical characteristics, 31/102 samples yielded S. aureus and 10/102 samples yielded E. coli. Out of $31 \mathrm{~S}$. aureus isolates, mecA gene was positive in $05(16.1 \%)$ and out of $10 \mathrm{ESBL}$ producing $E$. coli isolates bla TEM was positive in $02(20 \%)$ isolates. Coexpression of bla TEM and mecA genes was recorded only in $01(10 \%)$ isolate.

Key words: Buffaloes, Coexpression, ESBL, Mastitic milk, Polymerase chain reaction.
\end{abstract}

\section{INTRODUCTION}

Mastitis is inflammation of parenchyma of mammary glands or udder and is characterized by physical, chemical and usually bacteriological changes in milk and pathological changes in glandular tissues of udder (Radostits et al., 2000). Mastitis is considered to be the most common cause of injudicious antibiotic use in dairy animals such as wrong drug dose, or duration contribute to the increase in antimicrobial resistance without improving the outcome of treatment (Williams, 2000).

Mastitis is generally classified into clinical and subclinical mastitis. Clinical mastitis is characterized by local (e.g. swelling of the udder, heat and pain) or systemic (e.g. fever, anorexia, depression) while, subclinical mastitis is characterized by symptoms with milk abnormalities (e.g. milk clots, flakes, watery secretions, blood) (Gruet et al., 2001). Bacteria causing mastitis are of two types based upon their primary reservoir and mode of transmission. Environmental bacteria include coliform species like E. coli, Klebsiella sp. and species of Streptococci. These arise from the environment in which the buffalo lives, when teats are exposed to mud and manure and dirty bedding materials. Contagious Bacteria like Staphylococcus aureus, Streptococcus agalactiae are transmitted among cows by contact with infected milk (Cremonesi et al., 2006).

In India the prevalence of bovine mastitis due to Staphylococcus aureus (S.aureus) is around $30-40 \%$ (Patel et al., 2012 and Sharma et al., 2012). Mastitis caused by Staphylococcus aureus bacteria is extremely difficult to control by treatment alone because of property of methicillinresistant $S$. aureus (MRSA) to impart resistance to all $\beta$ lactam anti-microbial agents. $S$. aureus organisms colonize abnormal teat ends or teat lesions. It is capable of causing
Department of Veterinary Microbiology, College of Veterinary Science and Animal Husbandry, Nanaji Deshmukh Veterinary Science University, Jabalpur-482 001, Madhya Pradesh, India.

Corresponding Author: J. Jogi, Department of Veterinary Microbiology, College of Veterinary Science and Animal Husbandry, Nanaji Deshmukh Veterinary Science University, Mhow-453 441, Madhya Pradesh, India. Email: drjoycee@gmail.com

How to cite this article: Lade, A., Jogi, J., Nayak, A., Singh, R.V., Rai, A., Shakya, P., Himani, K. and Bordoloi, S. (2022). Co expression of Methicillin-resistant $S$. aureus and ESBL Producing E. coli in Mastitic Milk of Buffaloes. Indian Journal of Animal Research. DOI: 10.18805/IJAR.B-4835.

Submitted: 25-11-2021 Accepted: 01-02-2022 Online: 04-03-2022

peracute, acute, subacute, chronic, gangrenous and subclinical types of mastitis. The acute form of the disease usually occurs shortly after parturition and tends to produce gangrene of the affected quarters with high mortality (Rahmanet al., 2010 and Sharma and Maiti, 2010).

Escherichia coli (E. coli) is also reported to be one of the commonest pathogens in mastitis and the infected quarter shows swelling, pain with discharge of watery or bloody milk. Necrosis of the mammary epithelium occurs during severe, naturally occurring clinical $E$. coli mastitis, as well as during severe experimental $E$. coli mastitis (Bradley and Green, 2001). The multiplicity of the cause and emergence of resistance due to indiscriminate and prolonged use of antibiotics in absence of antibiogram is a major hurdle in the control of mastitis (Jeykumar et al., 2013). Early identification of the prevalence and distribution of causative pathogens is one of the important prerequisites to effectively prevent diseases and to guide treatment. So 
far, the prevalence of Methicillin resistant $S$. aureus and Extended spectrum beta lactamase E.coli in mastitic milk samples of buffaloes in Jabalpur region of Madhya Pradesh is not known.

Therefore, the present study was conducted to determine the prevalence of Methicillin resistant S.aureus and Extended spectrum beta lactamase E.coli in mastitic milk samples of buffaloes by means of phenotypic and genotypic characterization.

\section{MATERIALS AND METHODS}

A total of 408 buffaloes milk samples were screened from private dairy farms and adopted villages in and around Jabalpur city for the presence of subclinical mastitis by California mastitis test (Ruegg and Reinemann, 2002; Dhakal, 2006). Milk from infected quarter or udder with CMT score of $\geq 1$ was aseptically collected in sterile tubes transported in ice and stored at $-20^{\circ} \mathrm{C}$ until further use. Isolation of Methicillinresistant S.aureus and ESBL producing E. coliwas carried out according to the protocol published by EFSA, 2012 and Markey et al. (2013) respectively.

Pre-enrichment of $S$. aureus was performed in Mueller Hinton (MH) broth (HiMedia) supplemented with $6.5 \% \mathrm{NaCl}$ at $35^{\circ} \mathrm{C}$ for $16-20$ hours; followed by enrichment in Tryptone Soya Broth (HiMedia) with $3.5 \mathrm{mg} / \mathrm{L}$ cefoxitin (Sigma) and $75 \mathrm{mg} / \mathrm{L}$ aztreonam (Sigma) at $35^{\circ} \mathrm{C}$ for $16-20$ hours. The HiChromeMeReSa agar plates with cefoxitin and methicillin supplement (HiMedia) were used as selective agar and were incubated at $35^{\circ} \mathrm{C}$ for $16-20$ hours. Up to five blue-green colonies indicative of being MRSA were chosen and were streaked in Tryptone soy agar and incubated at $35^{\circ} \mathrm{C}$ for 16-20 hours. Pre-enrichment of $E$. coli was performed in buffered peptone water and incubated at $37^{\circ} \mathrm{C}$ for $18 \mathrm{hrs}$; followed by enrichment in Lauryl Tryptose broth and incubated at $37^{\circ} \mathrm{C}$ for $48 \mathrm{hrs}$. The MacConkey+ Cefotaxime agar plates were used as selective agar and were incubated at $37^{\circ} \mathrm{C}$ for $24 \mathrm{hrs}$.

The presumptive isolates of $S$. aureus and $E$. coli were phenotypically characterized by performing biochemical tests. The genotypic characterization of the Methicillin- resistant $S$. aureus (MRSA) was done using PCR for the detection of mecA gene (EFSA, 2012) and ESBL producing E. coli forbla TEM gene. The PCR-amplified samples were analysed by agarose gel electrophoresis by using a horizontal $1.5 \%(\mathrm{w} / \mathrm{v})$ agarose gel in $1 \mathrm{X}$ Tris Borate EDTA (TBE) buffer $(\mathrm{pH} 8.3$; 89.0 mMTris, $89.0 \mathrm{mM}$ boric acid, $2.0 \mathrm{mM}$ EDTA) at 80 Volts for 2 hours. The PCR products were visualized and photographed on a Gel documentation unit (Alpha Innotech). The 100 base pair (bp) ladder molecular weight marker was run in parallel with the samples. The amplification of the mecA gene of $S$. aureus with a size of $162 \mathrm{bp}$ and bla TEM gene of $E$. coli with a size of 867 bp confirms resistance.

\section{RESULTS AND DISCUSSION}

\section{Prevalence of subclinical mastitis in buffaloes}

A total of 408 buffaloes milk samples from private dairy farms and adopted villages in and around Jabalpur citywere screened for mastitis by California Mastitis test (CMT). A total of 102 quarter or composite samples of milk with CMT score $\geq 1$ were collected. Out of the 102 milk samples collected from dairy buffaloes, a total of 92 samples were of subclinical mastitis. A prevalence of $22.54 \%$ of subclinical mastitis respectively was found in 102 mastitic buffalo milk samples. In India, the estimated prevalence of SCM was $46.35 \%$ obtained from the meta-analysis studies described during the period 1995-2014 as reported (Bangar et al., 2015). The overall prevalence of SCM in buffaloes on animal basis was $23.85 \%$ and $\mathrm{CM} 8.67 \%$, in organized farms as reported by Sharma et al. (2018).

Genotypic characterization of Methicillin-resistant $S$. aureus (MRSA) and ESBL producing $E$. coli by blaTEM gene

After screening of 102 milk samples for methicillin resistance in $S$. aureus, 05 isolates were found MRSA positive after phenotypic and genotypic characterization for both $S$. aureus and methicillin resistance. The prevalence of $4.9 \%$ MRSA in buffalo milk was recorded. In the present study, 05 (4.9\%) of $S$. aureus samples were found to be carrying a mec $A$ gene, thereby confirming them as MRSA as depicted in Plate 1. Song et al. (2016) also confirmed MRSA by detection of the mecA gene from $25.4 \%$ S. aureus samples. $13.9 \%$ confirmed as MRSA, in a similar study, conducted by Chandrasekaran et al. (2014) in Tamil Nadu India, MRSA was detected in $3.0 \%$ (12/409) of the mastitis milk samples. Similarly, Shrestha et al. (2021) found, two mastitis milk samples $6.9 \%(2 / 29)$ of $S$. aureus were found to be carrying a mecA gene. Likewise Li et al. (2015) conducted a study in Northwestern China in 2014 , a high prevalence $(56.5 \%$, $121 / 214)$ of $S$. aureus was determined, but only one isolate $(0.46 \%)$ was found to be MRSA. Shrivastava et al. (2017) studied prevalence and characterization of MethicillinResistant $S$. aureus (MRSA) mastitis in dairy cattle, strains were positive for mecA gene was $16.47 \%$ which is

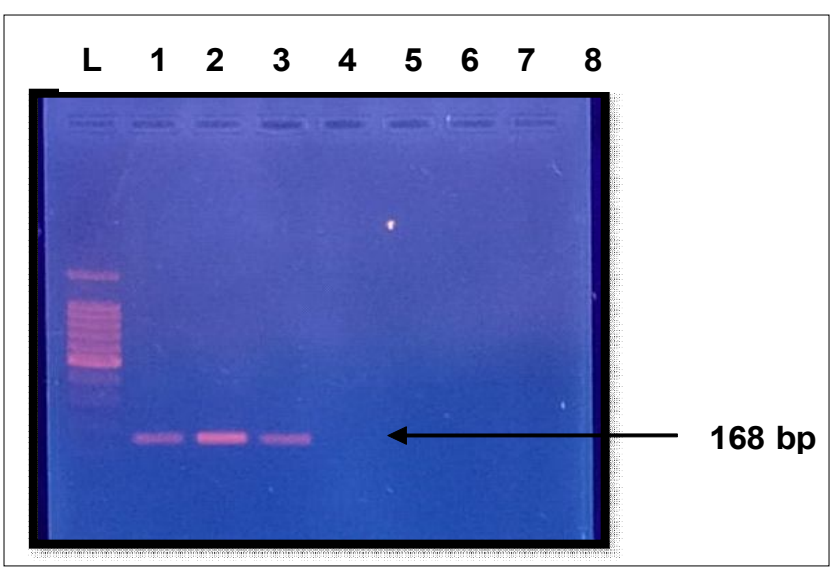

Plate 1: Agarose gel electrophoresis showing amplified product (168bp) ofmecA gene

$\mathrm{L}: 100$ bp DNA ladder (Promega).

Lane 1 and 2: Amplified product of $(\operatorname{mec} A)$ gene. Lane 3: Positive control. 


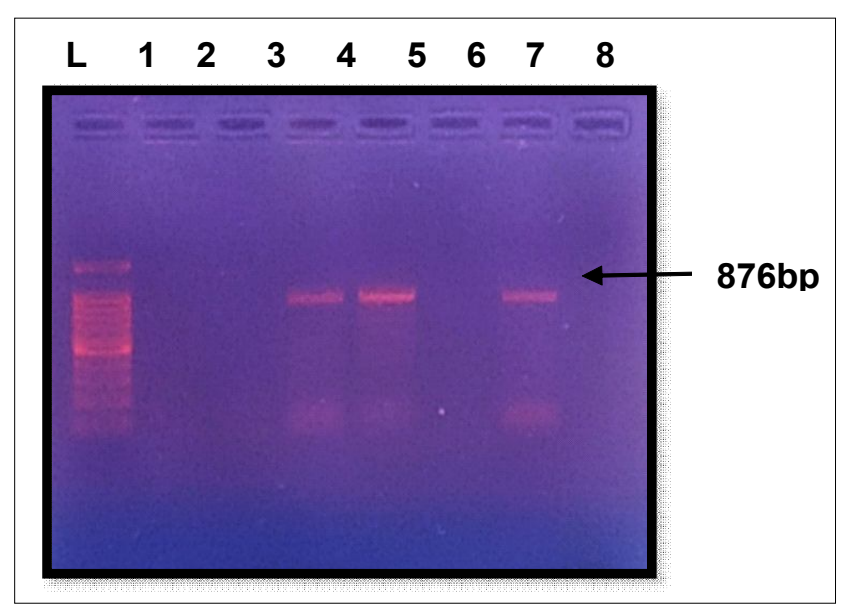

Plate 2: Agarose gel electrophoresis showing amplified product (867 bp) of bla TEM gene.

L : 100 bp DNA ladder (Promega).

Lane 3 and 4: Amplified product of (bla TEM) gene.

Lane 6: Positive control.

considered as a gold standard for the confirmation of methicillin resistance.

The present study was designed to detect the presence of ESBL producing $E$. coli in mastitic buffalo milk by characterization of beta lactamase gene. $10(10 \%)$ isolates were found to be phenotypically positive for E. coli. These isolates were checked for resistance, for blaTEM (867bp) by PCR assay as depicted in Plate 2. Out of the 10 E. coli isolates, $02(20 \%)$ were found positive for blaTEM gene. In the present study, 02 ESBL positive isolates (20\%) were isolated from organized dairy farms carrying a bla TEM gene Similarly, Olowe et al. (2015) performed PCR in E. coli isolates obtained from animal fecal samples in Nigeria and detected bla TEM and bla CTX gene in $48(42.10 \%)$ and 51 $(44.70 \%)$ isolates, respectively. Liu et al. (2018) from China reported $09.60 \%$ E. coli isolates from pigs as ESBL producer harbored at least one type of beta lactamase, with b/a CTX"M, bla TEM, being detected in $90.90 \%$ and $68.18 \%$, respectively. Abboud et al. (2021) investigated the etiology of the main mastitis causing pathogen and identified their antimicrobial resistance (AMR) ESBL gene, blaTEM in $(83.3 \%)$ E. coli isolates.

\section{Coexpression of methicillin-resistant S. aureus (MRSA) and ESBL producing $E$. coli}

The present study was designed to detect the Coexpression of Methicillin-resistant $S$. aureus (MRSA) and ESBL producing $E$. coli in mastitic buffalo milk by characterization of beta lactamase gene of $E$. coli and methicillin resistant gene of S.aureus.

Out of 05 MRSA isolates and $02 \mathrm{ESBL}$ isolates, Coexpression of bla TEM and mecA genes was recorded in only $01(10 \%)$ isolate.

Similarly, Bandyopadhyay et al. (2015) described intramammary infection of methicillin resistant $S$. epidermidis
(MRSE), methicillin resistant $S$. aureus (MRSA) and ESBL producing $E$. coli in two cows with subclinical mastitis and one with clinical mastitis in two different districts of West Bengal, India. In total, three such cases of bovine mastitis MRSE, one MRSA and three ESBL producing E. coli were isolated. Detection of simultaneous occurrence of MRSE, MRSA and ESBL producing $E$. coli in bovine mastitis in the present study indicates a major concern for dairy industry and public health as well.

However, very less reporting on simultaneous infection of MRSA and ESBL-producing E. coli in the same mastitic animal available to compare with the present findings.

\section{ACKNOWLEDGEMENT}

The authors would like to thank the owner of organized and unorganized farm for providing samples for the research work.

\section{Conflict of interest: None.}

\section{REFERENCES}

Abboud, Z., Galuppo, L., Tolone, M., Vitale, M., Puleio, R., Osman, M., Loria, G.R. and Hamze, M. (2021). Molecular characterization of antimicrobial resistance and virulence genes of bacterial pathogens from bovine and caprine mastitis in Northern Lebanon. Microorganisms. 9: 1148.

Bandyopadhyay, S., Samanta, I., Bhattacharyya, D., Nanda, P.K., Kar, D., Chowdhury, J., Dandapat, P., et al. (2015). Coinfection of methicillin resistant Staphylococcus epidermidis, methicillin resistant Staphylococcus aureus and extended spectrum $\beta$-lactamase producing Escherichia coli in bovine mastitis-three cases reported from India. Veterinary Quarterly. 35(1): 56-61.

Bangar, Y.C, Singh, B., Dohare, A.K. and Verma, M. (2015). A systematic review and meta-analysis of prevalence of subclinical mastitis in dairy cows in India. National Center for Biotechnology Information. 47(2): 291-7.

Bradley, A.J. and Green, M.J. (2001). Adaptation of Escherichia coli to the bovine mammary gland. Journal of Clinical Microbiology. 39: 1845-1849.

Chandrasekaran, D., Venkatesan, P., Tirumurugaan, K.G., Nambi, A.P., Thirunavukkarasu, P.S. and Kumanan, K. (2014). Pattern of antibiotic resistant mastitis in dairy cows. Veterinary World. 7(6): 389-394.

Cremonesi, P., Castiglioni, B., Malferrari, G., Biunno, I., Vimercati, C., Moroni, P., Morandi, S. and Luzzana, M. (2006). Improved method for rapid DNA extraction of mastitis pathogens directly from milk. Journal of Dairy Sciences. 89: 163-169.

Dhakal, I.P. (2006). Normal somatic cell count and subclinical mastitis in murrah buffaloes. Journal of Veterinary Medicine. 53: 81-86.

European Food Safety Authority. (EFSA). (2012). Technical specifications on the harmonised monitoring and reporting of antimicrobial resistance in methicillinresistant Staphylococcus aureus in food-producing animals and food. 10: 2897-2957. 
Gruet, P., Maincent, P., Berhelot, X. and Kaltsatos, V. (2001). Bovine mastitis and intramammary drug delivery: Review and perspectives. Advances of Drug Delivery Reviews. 50: 245-259.

Jeykumar, M., Vinod, G., Bashir, B.P. and Krovvidi, S. (2013). Antibiogram of mastitis pathogens in the milk of crossbred cows in Namakkal district, Tamil Nadu.Veterinary World. 6(6): 354-356.

Li, G., Wu, C., Wang, X. and Meng, J. (2015a). Prevalence and characterization of Methicillin susceptible Staphylococcus aureus ST398 isolates from retail foods. International Journal of Food Microbiology. 196: 94-97.

Liu, X., Liu, H., Wang, L., Peng, Q., Li, Y., Zhou, H. and Li, Q. (2018). Molecular characterization of Extended Spectrum $\beta$-lactamase producing multidrug resistant Escherichia coli from swine in Northwest China. Frontiers in Microbiology. 9: 1-11.

Markey, B., Leonard, F., Archambault, M., Cullinane, A. and Maguire, D. (2013). Clinical Veterinary Microbiology, $2^{\text {nd }} E d n$. Mosby, Elsevier, USA. 255 -266.

Olowe, O.A., Adewumi, O., Odewale, G., Ojurongbe, O. and Adefioye, O.J. (2015). Phenotypic and molecular characterisation of extended spectrum beta lactamase producing Escherichia coli obtained from animal fecal samples in Ado Ekiti, Nigeria. Journal of Environmental and Public Health. 2015: 1-7.

Patel, J.V., Bhingaradia, B.V., Patel, B.B., Patel, S.B., Patel, P.B. and Vahora, S.P. (2012). Study on prevalence of mastitis and antibiotic sensitivity of bacterial isolates recovered from cross-bred cows of Anand district of Gujarat. Indian Journal of Dairy Sciences. 65(6): 467-471.

Radostits, O., Gay, C., Blood, D. and Hinchcliff, K. (2000). Veterinary Medicine: A Textbook of the Diseases of Cattle, Sheep, Pigs, Goats and Horses, $10^{\text {th }}$ Edn., NY: WB Saunders, New York. 2065 p.
Rahman, M.M., Islam, M.R., Uddin, M.B. and Aktaruzzaman, M. (2010). Prevalence of subclinical mastitis in dairy cows reared in Sylhet District of Bangladesh. International Journal of Biology Research. 103: 23-28.

Ruegg, P. and Reinemann, D.J. (2002). Milk quality and mastitis tests. Bovine Pr. 36: 344-356.

Sharma, N. and Maiti, S.K. (2010). Incidence, etiology and antibiogram of sub clinical mastitis in cows in Durg, Chhattisgarh. Indian Journal of Veterinary Research. 19: 45-54.

Sharma, N., Rho, G.J., Hong, Y.J., Kang, T.Y., Lee, H.K., Hur, T.Y. and Jeong, D.K. (2012). Bovine mastitis: An asian perspective. Asian Journal of Veterinary Advances. 7: 454-476.

Sharma, N., Huma, Z., Singh, S.G., Navjot, Sharma, S., Gupta, S.K. and Upadhyay, S.R. (2018). Prevalence of clinical and subclinical mastitis in buffaloes of Jammu region. International Journal of Agriculture, Environment and Biotechnology. 11(2): 415-420.

Shrestha, A., Bhattarai, R.K., Luitel, H., Karki, S. and Basnet, H.B. (2021). Prevalence of methicillin-resistant Staphylococcus aureus and pattern of antimicrobial resistance in mastitis milk of cattle in Chitwan, Nepal. BMC Veterinary Research. 17: 1-7.

Shrivastava, N., Sharma, V., Nayak, A., Shrivastava, A.B., Sarkhel, B.C., Shukla P.C. and Shrivastava, A. (2017). Prevalence and characterization of Methicillin-resistant Staphylococcus aureus (MRSA) mastitis in dairy cattle in Jabalpur, Madhya Pradesh. Journal of Animal Research. 7: 77-84.

Song, J.W., Yang, S.J., Shin, S., Seo, K.S., Park, Y.H. and Park, K.T. (2016). Genotypic and phenotypic characterization of Methicillin-Resistant Staphylococcus aureus isolated from bovine mastitic milk in Korea. Journal of Food Protection. 79(10): 1725-1732.

Williams, R. (2000). The impact of antimicrobial resistance. Acta Veterinaria Scandinavica. Supplement. 93: 17-20. 